\title{
Annales Missiologici Posnanienses
}

Том 18, 2012

ALDONA MARIA PIWKO

\section{Kilka uwag o genezie islamu w Afryce Północnej}

Some remarks on the Islam's origins in the North Africa

Islam powstał w VII wieku na terenach Półwyspu Arabskiego. Głoszona przez Mahometa idea Boga Jedynego, zdobywała powoli, ale systematycznie nowych wyznawców. Wkrótce po śmierci największego proroka muzułmanów, rozpoczął się czas ekspansji nowej religii w świecie. Wierni Allaha działania, zmierzające do wprowadzenia islamu w jak największej części globu, prowadzili na wielu frontach. Pierwszym z nich był pochód na Zachód, przez tereny Północnej Afryki. Dlatego też pierwszym krajem podbitym przez muzułmanów był Egipt. Rządy arabskie rozpoczęły się już w 642 roku, zaledwie dziesięć lat po śmierci Mahometa.

Jednak islam w Afryce Północnej to nie tylko wiara w Allaha oraz przestrzeganie surowych zasad religijnych. Dominacja muzułmańska na północy kontynentu posiada rozbudowaną strukturę administracyjno-gospodarczą, zrzeszającą sąsiednie kraje w celu poprawienia warunków socjalnych oraz ekonomicznych obywateli. Utworzone unie oraz sojusze mają na celu uniezależnienie się arabskich państw afrykańskich od otaczających ich potęg gospodarczych Europy, a także Bliskiego Wschodu.

\section{ELEMENTY CHARAKTERYSTYCZNE PÓŁNOCNEJ AFRYKI}

Mianem Afryki Północnej określa się północne wybrzeże kontynentu, do którego zaliczane są następujące państwa: Algieria, Egipt, Libia, Maroko, Mauretania, Sahara Zachodnia, Tunezja. Elementami wspólnymi, łączącymi te państwa jest religia i kultura islamu, dominująca na omawianym terytorium. Jednocześnie dla prawidłowego zrozumienia wyjątkowości wymienionych państw na tle całej Afryki należy wyjaśnić kilka kwestii, głównie terminologicznych oraz organizacyjnych. 


\section{KRAJE ARABSKIE}

„Krajami arabskimi” określa się te państwa, w których dominującą grupę ludności stanowią Arabowie. Niemniej jednak istnieje duża trudność w dokładnym zdefiniowaniu pojęcia „kraj arabski”, ze względu na kilka elementów, które go wyznaczają. Najczęściej są to kryteria językowe, historyczne, kulturowe oraz polityczne. Jednocześnie trzeba podkreślić, że krajów arabskich nie należy utożsamiać z krajami muzułmańskimi, ponieważ sama kultura arabska była kształtowana przez wiele różnych religii. Ponadto do krajów arabskich nie zalicza się tych państw, w których Arabowie stanowią mniejszość etniczną, np. Iran, Turcja, Francja. Niemniej jednak jest wiele państw silnie związanych politycznie, kulturowo i ekonomicznie z krajami arabskimi. Wynika to często z obecności dużej liczby wyznawców Allaha w danym kraju, a także z historycznych uwarunkowań danych terenów oraz arabskich wpływów kulturowych ${ }^{1}$. Kraje arabskie zrzeszone są w Lidze Państw Arabskich.

\section{Liga Państw Arabskich}

Liga Państw Arabskich jest organizacją międzynarodową, utworzoną 22 marca 1945 roku w Kairze. Komitet założycielski stanowiły państwa powiązane ze sobą wspólnym językiem, historią, kulturą i religią. Państwami założycielskimi było siedem krajów: Arabia Saudyjska, Egipt, Irak, Jemen, Jordania, Liban, Syria. Obecnie Liga Państw Arabskich zrzesza $22 \mathrm{kraje}^{2}$ oraz Organizację Wyzwolenia Palestyny. Siedzibą pozostaje Kair.

Po zakończeniu II wojny światowej powstawały nowe państwa arabskie. Celem powołania Ligi Państw Arabskich było zacieśnienie współpracy przede wszystkim politycznej, społecznej, ekonomicznej oraz edukacyjnej i kulturowej. Ważne zatem było zagwarantowanie równowagi politycznej krajów arabskich oraz utworzenie jednolitej siły opozycyjnej wobec ruchów syjonistycznych. Na tej podstawie można wyeksponować trzy zasadnicze cele działalności LPA. Fundamentem działalności organizacji jest dobra współpraca państw członkowskich wraz z koordynacją akcji politycznych. Ponadto wzajemna działalność gospodarcza i kulturalna na rzecz wszystkich Arabów³.

\footnotetext{
${ }^{1}$ Taka sytuacja ma miejsce w Afryce. Do krajów afrykańskich ściśle związanych z krajami arabskimi należą: Czad, Dżibuti, Erytrea, Komory, Somalia. Ponadto przykładem kraju związanego z arabizmem jest Izrael.

${ }^{2}$ Kolejnymi członkami Ligi Państw Arabskich byli: Libia (do 2002 roku), Sudan, Maroko, Tunezja, Kuwejt, Algieria, Zjednoczone Emiraty Arabskie, Bahrajn, Katar, Oman, Mauretania, Somalia, Palestyna, Dżibuti, Komory.

${ }^{3}$ Por. Z. Cesarz, Liga Państw Arabskich, [w:] Organizacje w stosunkach międzynarodowych. Istota, mechanizmy działania, zasięg, T. Łoś-Nowak (red.), Wrocław 2009, s. 178-193.
} 
Na czele LPA stoi sekretarz generalny. Od 1945 roku Liga posiadała siedmiu sekretarzy, przy czym pięciu pochodziło z Egiptu oraz po jednym z Tunezji i Libanu. Pierwszym sekretarzem Ligi Państw Arabskich, był Abdul Razek Azzam, pełnił on swoją funkcję w latach 1945-1952. Natomiast od 2001 roku do chwili obecnej LPA przewodzi Amre Mahmoud Moussa.

Państwa arabskie zrzeszone w LPA, a zarazem położone w Afryce Północnej to: Algieria, Egipt, Maroko, Mauretania, Sahara Zachodnia oraz Tunezja.

23 kwietnia 2009 roku Stolica Apostolska podpisała porozumienie z Liga Państw Arabskich ${ }^{4}$. Watykan reprezentowany był przez abp Dominique'a Mambertiego, szefa dyplomacji papieskiej, zaś LPA przez sekretarza generalnego Amra Moussę. Przyjęte wówczas „Memorandum of Underststanding” podkreśla obustronną współpracę w zakresie politycznym oraz kulturalnym. Szczególnym punktem umowy jest działalność na rzecz pokoju, bezpieczeństwa oraz stabilności regionalnej i międzynarodowej. Ponadto w dokumencie znalazły się propozycje dwustronnych konsultacji w zakresie działalności międzyreligijnych.

\section{Maghreb oraz Arabska Unia Maghrebu}

Afryka Północna uległa silnym procesom islamizacji, w wyniku ekspansji arabskiej w dobie średniowiecza. W związku z tym Arabowie zaczęli określać państwa Północnej Afryki słowem maghreb, które oznacza w języku arabskim zachód. Obecnie nazwa ta rozpowszechniona została w językach europejskich i jest stosowana w odniesieniu do krajów północno-zachodniej Afryki: Libii, Tunezji, Algierii, Maroka, Sahary Zachodniej i Mauretanii.

Państwa regionu Maghrebu utworzyły organizację międzynarodową pod nazwą Arabska Unia Maghrebu. Powołana ona została w 1989 roku, ale pomysł jej utworzenia powstał już w 1956 roku, po odzyskaniu niepodległości przez Maroko i Tunezję.

Motywem utworzenia Arabskiej Unii Maghrebu były popularne wówczas tendencje panarabskie. Doktryna polityczna określana mianem panarabizm, głosiła zjednoczenie wszystkich krajów arabskojęzycznych. Ruch ten swoje początki wziął od rozwoju XIX wiecznego arabskiego nacjonalizmu. Panarabizm przyczynił się również do powstania omawianej wcześniej Ligi Państw Arabskich5

Arabska Unia Maghrebu powołana została dopiero w 1989 roku. Podstawowym celem organizacji jest integracja państw członkowskich pod względem gospodarczym oraz politycznym. Każdy kraj członkowski przez rok pełni prezy-

\footnotetext{
${ }^{4}$ W literaturze stosowany jest również skrót LPA, określający Ligę Państw Arabskich.

${ }^{5}$ Por. A. Nowak, Organizacje integracji regionalnej w Afryce, [w:] Organizacje w stosunkach międzynarodowych..., dz. cyt., s. 374-375.
} 
dencję w Unii i mianuje własnego sekretarza generalnego. Krajami członkowskimi Arabskiej Unii Maghrebu są: Algieria, Libia, Maroko, Mauretania i Tunezja. Jednak trwający spór między Algierią i Marokiem o status Sahary Zachodniej Algieria chce przejać to terytorium od Unii, działalność Arabskiej Unii Maghrebu jest utrudniona. Rezultatem nieporozumień było odwoływanie szczytów organizacji. ${ }^{6}$

\section{ARABOWIE W AFRYCE}

Arabowie wywodzą się z grupy ludów semickich ${ }^{7}$, którzy język arabski uważają za rodzimy. Jednocześnie nie stanowią oni jednolitej grupy etnicznej. Arabowie ukształtowali się w wyniku wielowiekowego procesu mieszania się ludności koczowniczej z mieszkańcami podbijanych terenów Bliskiego Wschodu i Afryki Północnej. Fundament przynależności do Arabów stanowi autoidentyfikowanie się $\mathrm{z}$ tą grupą etniczną oraz używanie języka arabskiego ${ }^{8}$. Jednocześnie należy podkreślić, że bycie Arabem nie jest równoznaczne $\mathrm{z}$ byciem muzułmaninem, chociaż większość Arabów wyznaje islam. Natomiast panujący powszechnie stereotyp, zwłaszcza wśród Europejczyków oraz pozostałej ludności o korzeniach chrześcijańskich, utożsamia Arabów z muzułmanami.

Do VII wieku Arabowie zamieszkiwali tereny Półwyspu Arabskiego, nazywanego przez nich samych Dżazirat al-Arab, co oznacza „Wyspę Arabów”. Słowo $a r a b$ natomiast oznacza pustynię lub koczownika. Sam termin Arabowie znany był już w czasach biblijnych, bowiem w księdze Rodzaju w rozdziale 10 wymienione są plemiona arabskie. Momentem szczególnym w historii Arabów było powstanie islamu oraz zjednoczenie plemion zamieszkujących Półwysep Arabski przez Mahometa. Owo zjednoczenie było na tyle trwałe i dające poczucie siły w jedności plemion, że już w kilka lat po śmierci Mahometa, Arabowie rozpoczęli podbój znacznej części ówczesnego świata. Wojny toczone były wielokierunkowo, jednak w niniejszym opracowaniu zostaną przeanalizowane podoje północy kontynentu afrykańskiego. Już w latach 640-645 podbite zostały Egipt i Libia. Następnie w 647 roku Trypolis, zaś daleki zachód afrykański, tzw. Maghreb w latach 690-7099. Marsz wojsk arabskich przez tereny afrykańskie, otworzył drogę islamowi do Europy. Wojska muzułmańskie w łatwy sposób dotarły do Hiszpanii, gdzie przez blisko osiem wieków funkcjonował kalifat i emirat.

\footnotetext{
${ }^{6}$ Tamże.

${ }^{7}$ Ludy semickie - nazwa umowna, pochodząca od imienia biblijnego Sema, syna Noego. Ludy te posługują się językami z rodziny języków semickich. Określenie to wprowadził niemiecki filolog August Schlözer w 1781 roku. Por. Arabowie, [w:] Obyczaje, języki, ludy świata, B. Kaczorowski (red.), Warszawa 2006, s. 44-46.

${ }^{8}$ Por. A. Hourani, Historia Arabów, Gdańsk 2002, s. 22-24.

${ }^{9}$ Por. Arabowie, [w:] Obyczaje, języki, ludy..., dz. cyt., s. 47.
} 
Arabów można podzielić na dwie grupy: fellachów, a więc ludność osiadłą oraz Beduinów, czyli koczowników. Grupy te różnią się między sobą, nie tylko stylem życia, ale również obyczajami i dialektem.

Fellachowie są przede wszystkim ludnością rolniczą, zamieszkującą głównie Egipt. Wywodzą się ze starożytnego ludu mieszkańców doliny Nilu, zmieszanych z Arabami. Chociaż większość poddała się islamizacji, to jednak ok. 20\% fellachów pozostaje nadal wyznawcami Kościoła Koptyjskiego ${ }^{10}$.

\section{Beduini}

Beduini reprezentują koczownicze plemiona, wywodzące się z krajów arabskich, żyjące w Afryce Północnej oraz na Bliskim Wschodzie. W większości, Beduini są muzułmanami wyznającymi islam sunnicki, ale ich wierzenia „skażone" są elementami pogańskimi, wśród których często dominuje kult sił przyrody.

Głównym zajęciem i sposobem zarobkowania Beduinów jest hodowla zwierząt: wielbłądów, owiec i kóz. Cechą charakterystyczną Beduinów była rozbudowana autonomia wobec innych grup muzułmańskich. Wyrażone to było przede wszystkim we własnej administracji oraz prowadzonej polityce. Beduini często napadali na karawany, udające się do Mekki, dlatego też władcy państw arabskich liczyli się z ich potęgą. Ponadto egipscy Beduini pełnili kontrolę nad żeglugą po Nilu.

Napoleon miał powiedzieć o Beduinach następujące słowa: „sq oni największa plaga Egiptu, ale nie można pominać ich istotnej dziatalności, trzeba przyznać, że sq oni niezbędni. Bez nich ten piękny kraj nie mógłby utrzymać łaczności z Syria, Arabia, oazami, królestwem Sennaru, Darfurem Abisynia, Trypolitania i królestwem Fezzanu. Bez nich transport od Nilu do Morza Czerwonego i z Kairu do Suezu byłby niemożliwy”.

Obecnie około 2\% Beduinów nadal prowadzi tradycyjny, koczowniczy tryb życia. Rozprzestrzeniająca się urbanizacja świata, zmusiła plemię do zmiany sposobu zarobkowania. Coraz częściej Beduini zatrudniają się w obsłudze ruchu turystycznego, pełniąc funkcję przewodników po pustyni oraz oferując przejażdżki na wielbłądach. Jednak znaczna część Beduinów osiadła w miastach, pracując w usługach i przemyśle, jak również często pozostaje bez pracy, ze względu na gorsze wykształcenie.

Społeczeństwo beduińskie posiada prostą strukturę, której podstawę stanowią rody łączące się w większe jednostki - najczęściej plemiona. Zaś kilka plemion tworzy konfederację plemion. Na jej czele stoi rada starszych pod przewod-

\footnotetext{
${ }^{10}$ Kościół Koptyjski - ogólna nazwa dla kościołów północno-wschodniej części Afryki (Egipt, Etiopia, Erytrea). Kościoły między sobą różnią się w obrządku.
} 
nictwem pana, zwanego szajchem ${ }^{11}$. Uczeni muzułmańscy zgodni byli w swych opiniach, że obowiązujący wśród Beduinów ustrój społeczny oraz kodeks honorowy, zwany ird był idealny ${ }^{12}$.

\section{Berberowie}

Berberowie są rdzenną ludnością Afryki Północnej oraz Sahary. Ze względu na brak poczucia wspólnoty określali siebie mianem ,ludzi wolnych”. Berberowie na terenach północnej Afryki byli obecni już w starożytności. Grecy kolonizujący południowe wybrzeże Morza Śródziemnego nazywali ich różnie, w zależności od terenów, na których żyli. W Egipcie Berberów nazywano Libijczykami, zaś w Algierii i Maroku - Maurami. Trudnili się przede wszystkim pasterstwem, łowiectwem oraz rolnictwem, ale również byli najemnymi wojownikami.

Liczby ludności berberyjskiej nie można precyzyjnie określić, ze względu na postępujące procesy arabizacji ${ }^{13}$. Z ludności berberyjskiej wywodzili się cesarze oraz filozofowie, a wśród nich Tertulian i św. Augustyn. Natomiast współcześnie piłkarz Zinedine Zidane oraz aktorka Isabelle Adjani. Berberowie byli schrystianizowani, dopiero w VII wieku ulegli wpływom islamu oraz kulturze arabskiej. $\mathrm{W}$ dobie średniowiecza na omawianych terenach powstały potężne dynastie berberyjskie: Almorawidów, Almohadów, Marywidów, Zirydów, Abdalwadydów.

Berberowie przyczynili się do islamizacji strefy sawanny w Afryce Zachodniej, którą prowadzili od IX wieku. Podobnie jak Beduini, również Berberowie mimo przyjęcia islamu, zachowali przedmuzułmańskie praktyki religijne, wśród których znajduje się kult świętych oraz wynikająca z prawa zwyczajowego wysoka pozycja kobiety w społeczeństwie. Kobiety berberyjskie cieszą się szacunkiem mężczyzn, wyrażonym przede wszystkim w monogamii, a także posiadają prawo do decydowania o ważnych sprawach rodzinnych razem z mężem.

Ludność berberyjska zamieszkuje głównie tereny górskie i półpustynne. Społeczność ta charakteryzuje się strukturą patriarchalną, bowiem do dziś przetrwały zwyczaje plemienne. Zwierzchnictwo nad plemieniem pełni rada, zwana również dżama’a. Wybierany jest na czas kadencji wódz, którego władza jest jednak ograniczona. Niezależność wspólnot lokalnych opierała się na sojuszach, a także na budownictwie fortyfikacyjnym, zwanym agadir. Agadir był twierdzą wojsko-

\footnotetext{
${ }^{11}$ Szajch - zwany także szejk, określenie dosłownie znaczy „mężczyzna w podeszłym wieku, starzec"; jest to arabski tytuł honorowy, znany już w czasach przedmuzułmańskich, a przysługuje wodzom arabskich plemion, naczelnikom wsi, przywódcom bractw, przełożonym szkół muzułmańskich. Por. Y. Thoraval, Słownik cywilizacji muzutmańskiej, Katowice 2002, s. 277.

${ }^{12}$ Por. Arabowie, [w:] Obyczaje, języki, ludy..., dz. cyt., s. 92.

${ }^{13}$ Liczbę tę szacuje się na ok. $14 \mathrm{mln}$, z czego 9,5 mln żyje w Maroku, 4,5 mln w Algierii, a po 10 tys. w Tunezji i Egipcie.
} 
wą, którą najczęściej stanowił ufortyfikowany spichlerz. W nim gromadzono zapasy żywności na wypadek suszy, zaś podczas wojen mogły się w nim schronić kobiety i dzieci. Budowle te były potężne i masywne, a także kilkukondygnacyjne. Całość należała do wspólnoty lokalnej, przy czym każda rodzina posiadała osobne pomieszczenie ${ }^{14}$.

Gospodarkę Berberów stanowi hodowla oraz uprawa roli. Część społeczności zajmuje się również rzemiosłem. Berberowie słyną z produkcji białej broni, wyrobów ze skóry, dywanów oraz biżuterii. Od lat 60 . XX wieku arabskie władze Maroka i Algierii prowadzą politykę wynarodowienia i asymilacji Berberów, co wiąże się z silnym ruchem emigracyjnym, głównie do Francji. Natomiast od lat 80 . XX wieku intensywnie rozwija się ruch w obronie języka i kultury berberyjskiej. Szczególną cechą charakteryzującą to plemię jest język, dzielący się na trzy dialekty: rifijski dominujący na północy, tashelhit w zachodnim Atlasie oraz na wschodzie tamzight. Pierwotnie język Berberów był językiem pisanym, posiadającym własny alfabet. Obecnie zapisywany jest w transkrypcji arabskiej. Powstały również czasopisma: „Tafsut”, „Awal”, Études et Documentes Berbères", dzięki prężnie działającej i dosyć licznej grupie inteligencji berberyjskiej w Maroku, a także wsparciu marokańskiego króla Hasana II ${ }^{15}$.

\section{PODBÓJ MUZUŁMAŃSKI AFRYKI PÓŁNOCNEJ}

Plemiona koczownicze zamieszkujące tereny Półwyspu Arabskiego przystąpiły do ataku na ludy osiadłe. Niewątpliwie przyczyną tej decyzji było przywództwo charyzmatycznego Mahometa, który potrafił zjednoczyć różne rody i klany w jeden byt, a więc ummę - społeczność muzułmanów. Mahomet nie wskazał swojego następcy, pełniącego funkcję przywódcy, co stało się przyczyną różnicy zdań wśród najbliższych współpracowników proroka, a w konsekwencji doprowadziło nawet do schizmy na wyznawców sunnizmu i szyizmu. Jednak problemy związane $\mathrm{z}$ administrowaniem ummą nie przeszkodziły $\mathrm{w}$ prowadzeniu ożywionej polityki zagranicznej, wyrażonej w podbojach coraz większej części średniowiecznego świata ${ }^{16}$.

Pierwszym podbitym przez muzułmanów krajem w Afryce Północnej był Egipt. W 641 roku dokonali tego członkowie dynastii Umajjadów, którzy na swoją kwaterę główną wybrali Al-Fustat. Z tego miasta powstał później Kair. Zdominowanie Egiptu przez Arabów było szczególnie istotnym elementem

\footnotetext{
${ }^{14}$ Por. Agadir, [w:] Obyczaje, języki, ludy..., dz. cyt., s. 95.

${ }^{15}$ Por. Życie i czasy Berberów, [w:] Maroko, J. Zaborowska (red.), Warszawa 2006, s. 64-65.

${ }^{16}$ Por. P. Curtin, Afryka Pótnocna - na styku dwóch światów, [w:] Historia Afryki, P. Curtin (red.), Gdańsk 2003, s. 91-92.
} 
w historii kraju, bowiem w krótkim czasie państwo zostało zarabizowane i zislamizowane. Kolejnymi władcami Egiptu byli przedstawiciele dynastii Umajjadów, Abbasydów, Tulunidów, Fatymidów, Ajjubidów oraz dynastie mameluckie. Od XVI wieku do 1882 roku Egipt znajdował się pod jurysdykcją Imperium Osmańskiego.

Kolejnym zarabizowanym terytorium stała się Tunezja, która była ośrodkiem panowania Umajjadów w regionie. Tunezja broniła swego terytorium, a przewodniczyła im waleczna królowa o przydomku Al-Kahina, czyli Prorokini. Damiya, bo takie było prawdziwe imię królowej zjednoczyła plemiona berberyjskie i siły bizantyjskie w walce przeciwko arabskim najeźdźcom z terenów Arabii. Jej wojska wygrały dwie bitwy, by ulec w walce pod El-Dżem. Tak upadła starożytna Kartagina. Zwycięzcy Arabowie wybudowali własną stolicę - Kairuan ${ }^{17}$. Obecnie jest czwartym, świętym miastem dla wyznawców islamu.

W procesie arabizacji terenów południowego wybrzeża Morza Śródziemnego, należy zwrócić również uwagę na Maroko. Północna część kraju od najdawniejszych czasów zamieszkiwana była przez koczownicze plemiona berberyjskie, które w IV wieku przed Chrystusem utworzyły królestwo Mauretanii. Po wielu podbojach i wojnach, w VII wieku tereny Maroka zostały zajęte przez Arabów i włączone do kalifatu umajjadzkiego, z jego religią i kulturą ${ }^{18}$. Państwem władały liczne dynastie arabskie i berberyjskie. W 1660 roku tron Maroka został przejęty przez ród Alawitów, który sprawuje władzę do dziś.

Ekspansja islamu w Afryce Północnej wywołała nieodwracalne zmiany w relacjach społecznych, kulturowych i politycznych całego kontynentu afrykańskiego. Północne kraje na zawsze włączone zostały do świata muzułmańskiego. Jednocześnie należy podkreślić, że osiedlenie się muzułmanów na całej północy Afryki, prawie uniemożliwiło do 1500 roku komunikację Europy z Afryką Centralną i Południową ${ }^{19}$. Po upadku dominacji dynastii Umajjadów, władzę w Imperium Muzułmańskim przejęli Abbasydzi.

Następujące po sobie liczne bitwy i wojny międzyplemienne, a także międzykontynentalne, w tym także dziewiętnastowieczna aneksja terenów Tunezji, Algierii i Maroka przez Francję oraz Libii przez Włochy, nie zdołały wykorzenić islamu z terytorium Afryki Północnej, a państwa te nie zatraciły swojej tożsamości religijno-kulturowej. Do dziś pas ten znajduje się pod silnymi wpływami religii oraz kultury islamu. Państwa Maghrebu stanowiły rodzaj buforu, dzielący łacińską Europę i tradycyjną kulturę Afryki.

Interesującym jest również postrzeganie i praktykowanie zasad islamu przez mieszkańców państw Maghrebu. Znacząca odległość od ośrodka władzy kalifa

\footnotetext{
${ }^{17}$ Por. Podbój Arabski, [w:] Tunezja, J. Zaborowska (red.), Warszawa 2005, s. 34-35.

${ }^{18}$ Por. A. Dziubiński, Historia Maroka, Wrocław 1983, s. 31-34.

19 Tamże, s. 95-96.
} 
w Bagdadzie sprzyjała „samodzielnemu” myśleniu. Takie warunki umożliwiały rozwój nauki oraz niezbyt ortodoksyjne praktykowanie islamu. Spowodowało to znaczną liberalizację islamu, szczególnie widoczną we współczesnych krajach Maghrebu. Ponadto brak ortodoksji religijnej uprawniał uczonych do upominania miejscowych władców w zakresie moralności i złego prowadzenia się dworu w Kairuanie.

\section{ROZWÓJ CYWILIZACJI MUZUŁMAŃSKIEJ W MAGHREBIE}

Muzułmańscy arabowie wraz $\mathrm{z}$ religią zaszczepili $\mathrm{w}$ tym regionie również własną filozofię oraz kulturę. Oprócz potyczek wojennych, których wynikiem było poszerzanie wpływów politycznych, ekspansja islamu w Afryce Północnej dotyczyła także sfery intelektualnej. Terytoria południowego wybrzeża Morza Śródziemnego zrodziły wielu wybitnych myślicieli oraz uczonych arabskich, którzy odcisnęli ślad na całym muzułmańskim dorobku naukowym.

Już w X wieku egipscy Fatymidzi założyli jeden z pierwszych, średniowiecznych uniwersytetów, Al-Azhar w Kairze wraz z bogatą biblioteką. Na uwagę zasługują również dokonania Ibn Tumarta, XII wiecznego przywódcy berberyjskiego plemienia Masmuda, który zreformował religię. Był zafascynowany myślą Al-Ghazaliego, a wyrażając zgodę na alegoryczne pojmowanie tekstów Koranu, wprowadził swobodę w interpretacji słów Allaha. Ponadto możliwe stały się badania naukowe oraz rozwój filozofii ${ }^{20}$.

Przychylność władców dynastii muzułmańskich do rozwoju nauki, a zwłaszcza matematyki oraz medycyny, zaowocowała znakomitymi uczonymi, którzy wnieśli znaczny wkład w rozwój ogólnoświatowej wiedzy o tych dziedzinach. Lekarze oraz filozofowie, przybywający na dwory północnoafrykańskie, a zwłaszcza marokański pochodzili z Andaluzji. O rozkwicie nauki w Maghrebie, mówiono wówczas: „W tym kraju wschodzą słońca i księżyce nauk”21. Wśród najwybitniejszych uczonych znalazł się największy, po Ar-Razim², arabski lekarz Avenzoar, będący również autorem kilku prac naukowych. Interesował się właściwą dietą oraz wpływem klimatu i warunków życia na zdrowie człowieka. Jako pierwszy opisał świerzb. Innym uczonym doskonalącym swoje umiejętności na dworze marokańskich władców był Abubacer matematyk, poeta i lekarz. W swoich dziełach opisywał zdolności ludzkiego rozumu do pojmowania prawd najbardziej abstrakcyjnych ${ }^{23}$. Także Awerroes jeden z największych muzułmańskich

${ }^{20}$ Por. A. Dziubiński, Historia Maroka..., dz. cyt., s. 90-92.

${ }^{21}$ Tamże, s. 91.

${ }^{22}$ Ar-Razi uważany jest za najwybitniejszego arabskiego lekarza, ojca medycyny arabskiej.

${ }^{23}$ J. Bielawski, Ibn Tufajl, [w:] Maty słownik kultury świata arabskiego, J. Bielawski (red.), Warszawa 1971, s. 221-222. 
filozofów, a zarazem matematyk, lekarz i prawnik znalazł azyl w Marrakeszu, po wygnaniu z Kordoby za nieprawowierne poglądy filozoficzne ${ }^{24}$.

Przychylność władców wobec naukowców, sprawiła, że intensywnie postępował rozkwit życia miejskiego i intelektualnego. Przyczyniła się do tego działalność filozofów, z których najwybitniejszym był Ibn Tufajl, żyjący w XII wieku. Jak większość ówczesnych uczonych, zajmował się wieloma dziedzinami wiedzy, był także nadwornym lekarzem. Zasłynął dziełem filozoficznym, zatytułowanym „Żyjący syn Czuwającego”, stanowiącym próbę pogodzenia filozofii $\mathrm{z}$ religia, pozostając $\mathrm{w}$ zgodzie $\mathrm{z}$ islamem. Co ciekawe studiując dzieło, można stwierdzić, że Ibn Tufajl daje przewagę filozofii, a więc rozumowi, przed prawdami religijnymi. Bohater dzieła, sam poznaje prawa rządzące światem, bez udziału pierwiastka religijnego. Owszem owo poznanie jest zgodne z islamem, ale jednocześnie jest to element wtórny ${ }^{25}$.

Istotną osobą w kształtowaniu afrykańskiej myśli muzułmańskiej był również Ibn Chaldun. Tunezyjczyk, arabski filozof, twórca arabskiej filozofii historii i socjologii. Jego dokonania znacząco odcisnęły się na kulturze średniowiecznej. Jest autorem historii uniwersalnej „Kitāb al-'ibar”, złożonej z siedmiu ksiąg, ale pierwsza „Al-Muqaddima” („Prolegomena”) postrzegana jest jako odrębne dzieło. Przez muzułmanów uważana jest za najważniejsze dzieło myśliciela, bowiem w niej przeprowadził analizę historii islamu, której fundament stanowią fakty. Ibn Chaldun stworzył własną metodologię, za pomocą której badał przyczyny awansu i upadku dynastii arabskich ${ }^{26}$. Uważał także, że koczownicy są bardziej wytrwali w dążeniu do wyznaczonych celów, są bardziej waleczni i lepiej potrafią współpracować, niż społeczności prowadzące osiadły tryb życia. Uważał, że z tego powodu, państwa zamieszkałe przez ludy osiadłe stają się coraz słabsze militarnie, co zachęcało nieprzyjaciół do podbojów ${ }^{27}$. Można również stwierdzić, że Ibn Chaldun opracował nową dziedzinę wiedzy „,naukę o społeczeństwie”.

Obecność islamu w Afryce Północnej posiada czternastowiekową tradycję. W tym czasie przez kraje Maghrebu przetoczyły się liczne bitwy oraz wojny. Miały one znaczący wpływ na historię, a także politykę tych ziem, natomiast nie spowodowały odejścia od religii i kultury islamu. Uczeni wywodzący się z omawianych terenów, wnieśli wkład w rozwój cywilizacji oraz nauki ogólnoświatowej, a z ich dorobku często korzystamy również w czasach współczesnych.

${ }^{24}$ Por. D. Lindberg, Recepcja optyki arabskiej na Zachodzie, w: Historia nauki arabskiej. Tom 2 Nauki matematyczne i fizyka, R. Rashed (red.), Warszawa 2001, s. 348-350.

${ }^{25}$ Por. J. Legowicz, Zarys historii filozofii, Warszawa 1967, s. 173.

${ }^{26}$ Por. M. Dziekan, Pisarze muzutmańscy VII-XX w., Warszawa 2003, s. 59-60.

${ }^{27}$ Por. P. Curtin, Afryka Pótnocna ..., dz. cyt., s. 138-139. 


\section{SUMMARY}

The first country conquered by Muslims in North Africa was Egypt. Arabic rules started there already in 642, only ten years after Muhammad's death. North Africa underwent a strong processes of islamization as a result of the Arabic expansion in the Middle Ages. Arabs started to refer to these territories of North Africa as „Maghreb" - Arabic word for "West”. The expansion of the Islam caused irreversible changes of African continent in all social, cultural and political dimensions.

\section{Key words:}

Islam, North Africa, Arab League, Arab Maghreb Union

\section{Słowa klucze:}

Islam, Afryka Północna, Liga Państw Arabskich, Arabska Unia Maghrebu 